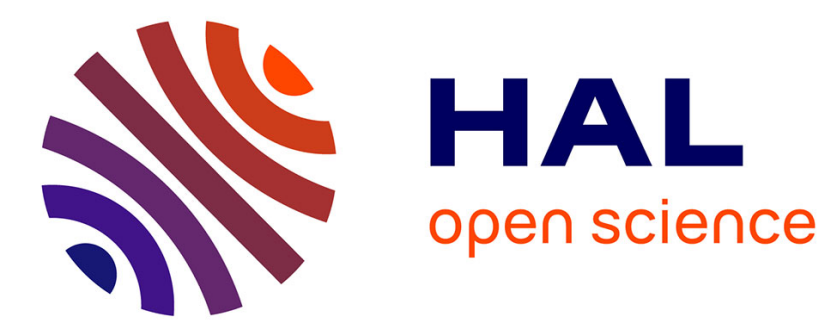

\title{
Antimicrobial susceptibility of tigecycline and comparators against bacterial isolates collected as part of the TEST study in Europe (2004-2007)
}

Niels Nørskov-Lauritsen, Hélène Marchandin, Michael J. Dowzicky

\section{- To cite this version:}

Niels Nørskov-Lauritsen, Hélène Marchandin, Michael J. Dowzicky. Antimicrobial susceptibility of tigecycline and comparators against bacterial isolates collected as part of the TEST study in Europe (2004-2007). International Journal of Antimicrobial Agents, 2009, 34 (2), pp.121. 10.1016/j.ijantimicag.2009.02.003 . hal-00556331

\section{HAL Id: hal-00556331 https://hal.science/hal-00556331}

Submitted on 16 Jan 2011

HAL is a multi-disciplinary open access archive for the deposit and dissemination of scientific research documents, whether they are published or not. The documents may come from teaching and research institutions in France or abroad, or from public or private research centers.
L'archive ouverte pluridisciplinaire HAL, est destinée au dépôt et à la diffusion de documents scientifiques de niveau recherche, publiés ou non, émanant des établissements d'enseignement et de recherche français ou étrangers, des laboratoires publics ou privés. 


\section{Accepted Manuscript}

Title: Antimicrobial susceptibility of tigecycline and comparators against bacterial isolates collected as part of the TEST study in Europe (2004-2007)

Authors: Niels Nørskov-Lauritsen, Hélène Marchandin, Michael J. Dowzicky

PII: S0924-8579(09)00067-3

DOI:

Reference: doi:10.1016/j.ijantimicag.2009.02.003

ANTAGE 2983

To appear in: International Journal of Antimicrobial Agents

Received date: $\quad 16-12-2008$

Revised date: $\quad$ 2-2-2009

Accepted date: $\quad 2-2-2009$

Please cite this article as: Nørskov-Lauritsen N, Marchandin H, Dowzicky MJ, Antimicrobial susceptibility of tigecycline and comparators against bacterial isolates collected as part of the TEST study in Europe (2004-2007), International Journal of Antimicrobial Agents (2008), doi:10.1016/j.ijantimicag.2009.02.003

This is a PDF file of an unedited manuscript that has been accepted for publication. As a service to our customers we are providing this early version of the manuscript. The manuscript will undergo copyediting, typesetting, and review of the resulting proof before it is published in its final form. Please note that during the production process errors may be discovered which could affect the content, and all legal disclaimers that apply to the journal pertain. 


\title{
Antimicrobial susceptibility of tigecycline and comparators against bacterial isolates collected as part of the TEST study in Europe (2004-2007)
}

Niels Nørskov-Lauritsen ${ }^{a}$, Hélène Marchandin ${ }^{b, c, *}$, Michael J. Dowzicky ${ }^{d}$

a Department of Clinical Microbiology, Aarhus University Hospital, Skejby DK-8200 Aarhus N, Denmark

${ }^{\mathrm{b}}$ Centre Hospitalier Régional Universitaire de Montpellier, Hôpital Arnaud de Villeneuve, Montpellier Cedex 5, 34295 France

c Université Montpellier 1, EA 3755, Faculté de Pharmacie, Laboratoire de Bactériologie-Virologie-Contrôle microbiologique, Montpellier Cedex 5, 34093

\author{
France \\ ${ }^{d}$ Wyeth Pharmaceuticals, Collegeville, PA 19426, USA
}

Received 16 December 2008; accepted 2 February 2009

Keywords: Tigecycline; Longitudinal surveillance; Antimicrobial resistance; MRSA; Acinetobacter

* Corresponding author. Present address: Laboratoire de Bactériologie-VirologieContrôle microbiologique, Faculté de Pharmacie, 15 Avenue Charles Flahault, 34093 Montpellier Cedex 5, France. Tel.: +33 4676354 26; fax: +33 467634511 .

E-mail address: h-marchandin@chu-montpellier.fr (H. Marchandin). 


\section{Abstract}

Tigecycline is a broad-spectrum antimicrobial agent that has been approved for the treatment of skin and soft-tissue infections as well as intra-abdominal infections. The Tigecycline Evaluation and Surveillance Trial (TEST) is a global, longitudinal surveillance study established in 2004 to monitor the in vitro activity of tigecycline and comparator agents against key Gram-negative and Gram-positive pathogens. This report examines data obtained for 24748 isolates collected across 24 European countries between 2004 and 2007. Tigecycline, meropenem and imipenem were the most active antimicrobial agents against most Gram-negative isolates including multidrug-resistant Acinetobacter baumannii (15.7\% of the $A$. baumannii isolates in this study), extended-spectrum $\beta$-lactamse (ESBL)-producing Escherichia coli (8.5\% of E. coli) and ESBL-producing Klebsiella pneumoniae (13.6\% of K. pneumoniae). Only amikacin was active against $>90 \%$ of Pseudomonas aeruginosa isolates (92.8\% susceptible). Tigecycline, linezolid and vancomycin were the most active agents against Gram-positive agents across Europe between 2004 and 2007, with tigecycline displaying the lowest $\mathrm{MIC}_{90}$ values (minimum inhibitory concentration for $90 \%$ of the organisms) against meticillin-resistant Staphylococcus aureus $(26.5 \%$ of the collected S. aureus isolates), vancomycin-resistant Enterococcus faecium (15.7\% of the E. faecium strains) and penicillin-resistant Streptococcus pneumoniae (9.3\% of the S. pneumoniae strains). Longitudinal analysis showed no increase in tigecycline MIC values over the 4-year study period, whilst increased resistance was noted for several comparator agents. 


\section{Introduction}

The prevalence of antimicrobial resistance among bacterial pathogens has increased to worrying levels in recent years, resulting in more complicated treatment challenges and increased healthcare burdens $[1,2]$. Novel resistance mechanisms have evolved that can counter the effects of newer antimicrobial agents, such as the development of metallo- $\beta$-lactamases with activity against carbapenems [3]. The development of new antimicrobial agents active against emerging resistant pathogens is thus an essential process.

Tigecycline is a broad-spectrum antimicrobial agent and is the first member of a new class of antimicrobial agents, the glycylcyclines (derived from the tetracycline nucleus), to be made commercially available. Tigecycline is unaffected by most bacterial resistance mechanisms, including tetracycline resistance [4]. It is, however, susceptible to the multidrug efflux systems found in Pseudomonas aeruginosa and some Proteus spp. [5]. Tigecycline is active in vitro against diverse Gram-negative and Gram-positive pathogens, including meticillin-resistant Staphylococcus aureus (MRSA), vancomycin-resistant enterococci (VRE) and extended-spectrum $\beta$ lactamase (ESBL)-producing bacteria (including Escherichia coli and Klebsiella pneumoniae) [6]. Tigecycline is approved for the treatment of intra-abdominal infections and complicated skin and skin-structure infections [7].

This study reports on the antimicrobial susceptibility of a wide range of nosocomial and community organisms, including resistant pathogens, collected throughout Europe between 2004 and 2007 as a part of the Tigecycline Evaluation and 
Surveillance Trial (TEST). Rodloff et al. [8] have previously reported on tigecycline activity in Europe, examining data from isolates collected in France, Germany, Italy, Spain and the UK between 2004 and 2006. This report expands on that study by incorporating isolates from these same five countries plus several other European countries, bringing the total number of participating countries to 24 ; data are also expanded to include 2007 isolates, bringing the number of studied isolates to 24748 .

\section{Materials and methods}

\subsection{Collection of bacterial isolates}

Bacterial isolates were consecutively collected between 2004 and 2007 from the following European countries (number of centres in parentheses): Austria (2); Belgium (7); Croatia (2); Czech Republic (3); Denmark (3); Finland (3); France (16); Germany (13); Greece (5); Hungary (5); Ireland (4); Italy (21); Latvia (2); Lithuania (1); Norway (1); Poland (1); Portugal (1); Slovak Republic (1); Slovenia (2); Spain (9); Sweden (4); Switzerland (2); The Netherlands (2); and the UK (4). Not all centres contributed isolates in all years.

Participating laboratories annually provided up to 200 isolates for extended susceptibility testing. Isolates were collected from inpatients and outpatients with community-acquired or nosocomial infections where the pathogen collected was identified as the probable infecting organism. All body sites were considered acceptable sources for collection, including blood, respiratory tract, intra-abdominal material, wounds and urine (accounting for no more than $25 \%$ of all isolates from each centre). Only one isolate per patient was accepted into this study; inclusion was 
independent of medical history, age, gender or previous antimicrobial usage. Each participating centre was required to submit the following isolates in each year of participation in the TEST study: (number of isolates in parentheses): Acinetobacter spp. (15); Enterococcus spp. (15); Enterobacter spp. (25); E. coli (25); Klebsiella spp. (25); P. aeruginosa (20); S. aureus (25); Serratia spp. (10); Haemophilus influenzae (15); Streptococcus agalactiae (10); and Streptococcus pneumoniae (15).

A single laboratory [Laboratories International for Microbiology Studies, a division of International Health Management Associates, Inc. (IHMA), Schaumburg, IL] was responsible for the co-ordination of isolate collection, transport and confirmation of isolate identification. Quality control checks were carried out on ca. $10 \%$ of contributed isolates.

\subsection{Susceptibility testing}

Minimum inhibitory concentrations (MICs) were established at collecting medical centres using Clinical and Laboratory Standards Institute (CLSI) (formerly the National Committee for Clinical Laboratory Standards) broth microdilution methodology [9], using either MicroScan ${ }^{\circledR}$ panels (Dade Behring Inc., Sacramento, CA) or Sensititre ${ }^{\circledR}$ plates (TREK Diagnostic Systems, East Grinstead, UK). Gramnegative organisms were investigated against the following antimicrobial agents (concentration ranges in $\mathrm{mg} / \mathrm{L}$ in parentheses): amikacin (0.5-64); amoxicillin/clavulanic acid (0.12/0.06-32/16); ampicillin (0.5-32); cefepime (0.5-32); ceftriaxone (0.06-64); ceftazidime (8-32); imipenem (0.06-16; MicroScan ${ }^{\circledR}$ only); meropenem (0.06-16; Sensititre ${ }^{\circledR}$ only); levofloxacin (0.008-8); minocycline (0.516); tigecycline (0.008-16); and piperacillin/tazobactam (0.06/4-128/4). Gram- 
positive organisms were tested against: amoxicillin/clavulanic acid (0.03/0.015-8/4); ampicillin (0.06-16); penicillin (0.06-8); linezolid (0.5-8); ceftriaxone (0.03-64); imipenem (0.12-16; MicroScan ${ }^{\circledR}$ only); meropenem (0.12-16; Sensititre ${ }^{\circledR}$ only); levofloxacin (0.06-32); minocycline (0.25-8); tigecycline (0.008-16);

piperacillin/tazobactam (0.25/4-16/4); and vancomycin (0.12-32). In 2006, imipenem was replaced by meropenem in the TEST antimicrobial panel owing to imipenem stability issues. Quality control testing was carried out on each day of MIC testing using E. coli ATCC 25922 and 35218, S. aureus ATCC 29213, P. aeruginosa ATCC 27853, Enterococcus faecalis ATCC 29212 and S. pneumoniae ATCC 49619 (as appropriate). Susceptibility was determined using CLSI interpretive criteria [10], with the exception of tigecycline for which European Committee on Antimicrobial Susceptibility Testing (EUCAST) (http://www.srga.org/eucastwt/MICTAB/index.html) breakpoints were used (Enterobacteriaceae, susceptible $\leq 1 \mathrm{mg} / \mathrm{L}$, resistant $\geq 4 \mathrm{mg} / \mathrm{L}$; $S$. aureus, susceptible $\leq 0.5 \mathrm{mg} / \mathrm{L}$, resistant $\geq 1 \mathrm{mg} / \mathrm{L}$; Enterococcus spp., susceptible $\leq 0.25 \mathrm{mg} / \mathrm{L}$, resistant $\geq 1 \mathrm{mg} / \mathrm{L})$.

\subsection{Resistance determination}

Meticillin resistance among isolates of $S$. aureus was detected using local methodologies; subsequent confirmation was carried out using the cefoxitin disk diffusion method (30 $\mu \mathrm{g}$ disks) (Remel Inc., Lenexa, KS) at the central laboratory. Penicillin-resistant S. pneumoniae (PRSP) are defined as having an MIC $\geq 2 \mathrm{mg} / \mathrm{L}$ and penicillin-intermediate S. pneumoniae as isolates with MICs $>0.06 \mathrm{mg} / \mathrm{L}$ and $<2$ $\mathrm{mg} / \mathrm{L}$. 
Multidrug resistance among isolates of Acinetobacter baumannii was defined as resistance to fluoroquinolones (levofloxacin) and aminoglycosides (amikacin) plus carbapenems (imipenem/meropenem) and/or third-generation cephalosporins (ceftazidime/ceftriaxone).

$\beta$-Lactamase production among $H$. influenzae isolates was determined using local methodologies. IHMA confirmed $\beta$-lactamase production in $H$. influenzae [using the Cefinase $^{\mathrm{TM}}$ disk test (BD Diagnostics, Sparks, MD)] only if an investigator's $\beta$ lactamase detection result and ampicillin or amoxicillin/clavulanic acid MICs were contradictory or when an investigator did not perform a $\beta$-lactamase determination. ESBL production was identified among $E$. coli and $K$. pneumoniae using the CLSI phenotypic disk test [10]; ESBL production was confirmed at IHMA by the doubledisk synergy test using disks containing cefotaxime (30 $\mu \mathrm{g})$, cefotaxime/clavulanic acid $(30 / 10 \mu \mathrm{g})$, ceftazidime $(30 \mu \mathrm{g})$ and ceftazidime/clavulanic acid $(30 / 10 \mu \mathrm{g})$. Phenotypic identification of ESBL production was not confirmed using molecular tools. Antimicrobial disks were manufactured by Oxoid Inc. (Ogdensburg, NY), whilst Mueller-Hinton agar was produced by Remel Inc. An inhibition zone size increase of $\geq 5 \mathrm{~mm}$ on the combination disk indicated a positive result for the presence of ESBL [10]. Quality control strains in this study included K. pneumoniae ATCC 700603 (used as a positive ESBL control) and $P$. aeruginosa ATCC 27853 and E. coli ATCC 25922 (used as a negative ESBL controls). 


\section{Results}

\subsection{Gram-negative isolates}

Susceptibility testing was performed on 16760 isolates across nine Gram-negative taxa; pooled data for these isolates are listed in Table 1. The most active agents against $A$. baumannii were tigecycline [MIC for $90 \%$ of the organisms $\left(\mathrm{MIC}_{90}\right)=1$ $\mathrm{mg} / \mathrm{L}]$ and minocycline $\left(\mathrm{MIC}_{90}=4 \mathrm{mg} / \mathrm{L} ; 94.2 \%\right.$ susceptible) (Table 1). Low $\mathrm{MIC}_{90}$ values $(\leq 2 \mathrm{mg} / \mathrm{L})$ were noted for tigecycline, imipenem and meropenem against Enterobacter aerogenes and Enterobacter cloacae (Table 1). Escherichia coli isolates were highly susceptible to tigecycline, imipenem and meropenem, with $\mathrm{MIC}_{90}$ values $<1 \mathrm{mg} / \mathrm{L}$. Escherichia coli resistance to tigecycline and imipenem did not change, whilst small increases in resistance [ranging from $0.1 \%$ (amikacin) to $6.6 \%$ (minocycline)] were noticed among all other agents (Table 1). Low $\mathrm{MIC}_{90}$ values ( $\leq 2 \mathrm{mg} / \mathrm{L})$ were noted for tigecycline, imipenem and meropenem against $K$. pneumoniae, and resistance to all antimicrobial agents increased during the study period with the exception of meropenem and tigecycline (for which decreases were noted) (Table 1). Low $\mathrm{MIC}_{90}$ values ( $\leq 2 \mathrm{mg} / \mathrm{L}$ ) were noted for levofloxacin, cefepime, tigecycline, imipenem and meropenem against Klebsiella oxytoca. $\mathrm{MIC}_{90}$ values for Serratia marcescens were $\leq 2 \mathrm{mg} / \mathrm{L}$ for tigecycline, cefepime, imipenem, meropenem and levofloxacin, whilst high susceptibilities were noted for cefepime, imipenem, meropenem and amikacin (Table 1). Serratia marcescens resistance to minocycline increased by $6.0 \%$, with a corresponding decrease in susceptibility from $85.1 \%$ in 2004 to $68.8 \%$ in 2007 (data not shown); susceptibility to tigecycline was stable. Haemophilus influenzae isolates were highly susceptible to most test agents (Table 
1). Few agents showed notable activity against $P$. aeruginosa, with amikacin the only agent inhibiting $>90 \%$ of isolates (Table 1 ).

Summary data (pooled) for important resistant Gram-negative pathogens are provided in Table 2. Multidrug-resistant (MDR) isolates represented $15.7 \%$ of all $A$. baumannii isolates, with the lowest $\mathrm{MIC}_{90}$ reported for tigecycline $(2 \mathrm{mg} / \mathrm{L})$ (Table 2$)$. A large decrease (45.4\%) in imipenem susceptibility was seen between 2004 and 2005 , likely due to the low number of isolates tested for imipenem in $2005(n=16)$. ESBLs were produced by 289 E. coli isolates (8.5\%); low $\mathrm{MIC}_{90}$ values were observed for meropenem $(0.12 \mathrm{mg} / \mathrm{L})$, tigecycline and imipenem (both $0.5 \mathrm{mg} / \mathrm{L}$ ) (Table 2). Tigecycline $\mathrm{MIC}_{90}$ values were stable over the 4 study years $(0.5 \mathrm{mg} / \mathrm{L}$ or 1 $\mathrm{mg} / \mathrm{L})$ (Table 2). ESBLs occurred in 316 K. pneumoniae isolates (13.6\%) (Table 2); the most active agents against these isolates were imipenem $\left(\mathrm{MIC}_{90}=0.5 \mathrm{mg} / \mathrm{L}\right)$, meropenem and tigecycline (both $=2 \mathrm{mg} / \mathrm{L}$ ) (Table 2). ESBL-positive $K$. pneumoniae showed increasing resistance to amoxicillin/clavulanic acid (18.4\%), levofloxacin (17.5\%) and piperacillin/tazobactam (15.1\%) (Table 2) and increasing susceptibility to tigecycline (12.5\%). Low $\mathrm{MIC}_{90}$ values were reported for most agents against $\beta$ lactamase-positive $H$. influenzae with the exception of ampicillin ( $\geq 64 \mathrm{mg} / \mathrm{L}$ ) and amikacin (8 mg/L) (Table 2).

\subsection{Gram-positive isolates}

Susceptibility testing was carried out on 7988 Gram-positive isolates spread over five species collected across Europe from 2004-2007. Pooled data are presented in Table 1. Tigecycline was the most active agent against both Enterococcus spp., with stable $\mathrm{MIC}_{90}$ values reported over the 4 -year study period $(0.25 \mathrm{mg} / \mathrm{L}$ for $E$. faecalis 
and $0.12 \mathrm{mg} / \mathrm{L}$ for Enterococcus faecium). Minocycline resistance among isolates of E. faecalis increased by $18.3 \%$ during this study. Low linezolid $\mathrm{MIC}_{90}$ values were also noted for $E$. faecium ( $2 \mathrm{mg} / \mathrm{L}$ ) during the study period but notable resistance increases were noted among several agents (Table 1). All S. aureus isolates were susceptible to linezolid and vancomycin; low $\mathrm{MIC}_{90}$ values were recorded for tigecycline $(0.25 \mathrm{mg} / \mathrm{L})$, minocycline $(0.5 \mathrm{mg} / \mathrm{L})$ and vancomycin $(1 \mathrm{mg} / \mathrm{L})$.

Staphylococcus aureus resistance decreased against most antimicrobials during this study (Table 1). Streptococcus agalactiae isolates were highly susceptible to most agents on the test panel, with the exception of minocycline (against which resistance increased by $14.5 \%$ ). Streptococcus pneumoniae $\mathrm{MIC}_{90}$ values of $\leq 1 \mathrm{mg} / \mathrm{L}$ were recorded for all antimicrobials with the exception of ampicillin and minocycline; high susceptibilities were noted to amoxicillin/clavulanic acid, ceftriaxone, levofloxacin, linezolid and vancomycin (Table 1).

Pooled summary data for key resistant Gram-positive pathogens are listed in Table 2. Of 491 E. faecium isolates, 77 (15.7\%) were vancomycin-resistant (Table 2); for this resistant subpopulation, the lowest $\mathrm{MIC}_{90}$ was reported for tigecycline $(0.12 \mathrm{mg} / \mathrm{L}$ overall, ranging from $0.06 \mathrm{mg} / \mathrm{L}$ in 2005 to $0.25 \mathrm{mg} / \mathrm{L}$ in 2007 ), whilst $71.4 \%$ and $79.2 \%$ were susceptible to minocycline and linezolid, respectively. Resistance to ampicillin increased by $23.1 \%$ among vancomycin-resistant $E$. faecium isolates, whilst levofloxacin resistance increased by $15.4 \%$ (Table 2). MRSA accounted for $26.5 \%$ of $S$. aureus isolates (Table 2 ) and were highly susceptible to tigecycline $\left(\mathrm{MIC}_{90}=0.25 \mathrm{mg} / \mathrm{L}\right)$, linezolid $\left(\mathrm{MIC}_{90}=4 \mathrm{mg} / \mathrm{L}\right)$ and vancomycin $\left(\mathrm{MIC}_{90}=1 \mathrm{mg} / \mathrm{L}\right)$ (Table 2). MRSA prevalence ranged from $0 \%(0 / 24)$ in Norway and The Netherlands $(0 / 49)$ to $48.8 \%$ in Greece (Table 3$)$ and $58.3 \%$ in Poland $(14 / 24)$ in this study. PRSP 
represented $9.3 \%(149 / 1602)$ of S. pneumoniae isolates (Table 3). Low $\mathrm{MIC}_{90}$ values ( $\leq 1 \mathrm{mg} / \mathrm{L})$ of tigecycline, imipenem, meropenem, levofloxacin, linezolid and vancomycin were noted for PRSP.

\subsection{Longitudinal analysis}

The yearly prevalence of key resistant Gram-negative and Gram-positive isolates for countries contributing $\geq 10$ isolates in at least 3 study years is presented in Table 3 . Overall, MDR A. baumannii percentages were stable, with the highest levels occurring in Greece (50.0\%) and Italy (36.0\%); rates increased in Italy $(19.1 \%$ in 2004 to $53.3 \%$ in 2007) but decreased in Spain (35.7\% in 2004 to $15.1 \%$ in 2007). Across Europe, ESBL-positive E. coli increased from 6.3\% in 2004 to $10.4 \%$ in 2007. The highest levels were reported in Greece (21.7\% over 2004-2007), ranging annually from $8.3 \%$ to $27.8 \%$ (Table 3 ). Notable ESBL-positive E. coli increases were reported for strains collected from Germany $(5.0 \%$ to $16.0 \%)$, Ireland $(0.0 \%$ to $20.0 \%$ ) and Spain (1.0\% to $12.9 \%$ ). ESBL-positive K. pneumoniae increased in the UK from $24.2 \%(16 / 66)$ in 2004 to $80.0 \%(16 / 20)$ in 2007. $\beta$-Lactamase-positive $H$. influenzae levels were stable across Europe, ranging from $14.6 \%$ in 2004 to $14.4 \%$ in 2007 (Table 3).

Only $17(1.2 \%)$ of 1433 E. faecalis isolates recorded across Europe were vancomycin-resistant; 13 of these were recovered in Italy, 6 of which were reported in 2004 (Table 3). The remaining vancomycin-resistant $E$. faecalis isolates were reported from the Czech Republic ( $n=1$, collected in 2007), Greece ( $n=1,2006)$, Ireland $(n=1,2007)$ and Latvia $(n=1,2005)$. Vancomycin-resistant $E$. faecium accounted for $15.7 \%(77 / 491)$ of all E. faecium isolates; again, the biggest 
contributor was Italy (29 isolates), with 19 isolates collected in 2006. MRSA rates were highest in Poland (58.3\%; data available for 2004 only, no isolates were contributed between 2005 and 2007), Greece (48.8\%) and Croatia (48.6\%; data available for 2006 and 2007 only, no MRSA isolates were contributed in 2004 or 2005), although Italy and France contributed the highest numbers of MRSA isolates (205 and 160, respectively). MRSA prevalence in Italy decreased (from $45.1 \%$ to $27.8 \%$ ), whilst rates in France were relatively stable (ranging from $35.8 \%$ in 2004 to $30.0 \%$ in 2007) (Table 3). PRSP prevalence increased from $7.1 \%(28 / 396)$ in 2004 to $11.2 \%$ (53/475) in 2007: levels increased most noticeably in Ireland (from $0.0 \%$ in 2004 to $29.2 \%$ in 2007), although total $N$ values were relatively low ( $N=15$ in 2004 and 24 in 2007). PRSP levels were highest overall in Finland (data not shown), occurring in $8(20.5 \%)$ of 39 S. pneumoniae isolates during the study period.

\section{Discussion}

TEST was initiated to monitor the presence and development of resistance to tigecycline among important bacterial pathogens globally, including various European countries [8]. Some general trends in resistance to antimicrobials in Europe are apparent from the data presented in the current study. For example, resistance among isolates of Acinetobacter spp. are on the increase. Acinetobacter spp. are opportunistic pathogens that commonly infect immunocompromised patients, causing an array of infections including nosocomial pneumonia, skin and soft-tissue infections and bacteraemia. Acinetobacter spp. (particularly A. baumannii) have become resistant to most of the major antimicrobial agents in widespread use, including aminoglycosides, quinolones, $\beta$-lactams, cephalosporins and also carbapenems [11,12]. Acinetobacter baumannii resistance rates are higher for 
piperacillin/tazobactam $(+5.2 \%)$, ceftazidime $(+6.5 \%)$ and meropenem $(+12.4 \%)$ in the current study than indicated by Turner et al. [11]. Although EUCAST has not designated Acinetobacter breakpoints for tigecycline, the $\mathrm{MIC}_{90}$ of $1 \mathrm{mg} / \mathrm{L}$ reported in the current study is the lowest of all antimicrobial agents tested, including the carbapenems. Tigecycline may thus be one of the few antimicrobial agents available today with good in vitro activity against this increasingly common MDR pathogen. Clinical data are currently lacking for tigecycline in the treatment of infections caused by Acinetobacter spp., although initial clinical results for tigecycline used in the treatment of complicated skin and soft-tissue infections due to A. baumannii are promising [13].

Similarly, E. coli susceptibility to fluoroquinolones and cephalosporins is lower in the current study than in other recent surveillance studies in Europe. As part of The Surveillance Network (TSN) study in 2000-2001, Wenzel et al. [14] reported ceftriaxone susceptibility ranging from $96.7 \%$ (Italy) to $99.8 \%$ (Germany); this decreased to $89.3 \%$ across Europe in the current study. Reduced susceptibility can also be seen among isolates of $E$. coli to ceftazidime (up to $5.7 \%$ ) and levofloxacin (as much as $14.7 \%$ ), although levofloxacin susceptibility was already decreasing in some European countries by $2000-2001$ (e.g. only $75.2 \%$ of isolates were susceptible in Spain) [14]. However, the in vitro susceptibility of $E$. coli to tigecycline and the carbapenems was high in the TEST study.

The decreased E. coli susceptibility to cephalosporins may be due to increases in the prevalence of the CTX-M ESBLs among E. coli isolates across Europe [15]. These ESBLs, particularly CTX-M-15, have been detected in various members of the 
Enterobacteriaceae family [16]. Similarly, decreased susceptibility of $K$. pneumoniae to third-generation cephalosporins over the study period, together with the increasing rate of ESBL-producing strains particularly observed in France and Ireland, may be attributed to the spread of ESBL-producing clones [15]. The dramatic increase in ESBL-positive K. pneumoniae reported in the UK in this study, rising from $24.2 \%$ in 2004 to $80.0 \%$ in 2006 , may be due in large part to the relatively low numbers of isolates collected (66 and 20 , respectively). Introduction of $\beta$-lactamase genotyping to the TEST study would help to reveal whether CTX-M-15 is responsible for changing patterns of resistance among E. coli and other Enterobacteriaceae across Europe.

$\beta$-Lactamase production is not the only route by which isolates of $H$. influenzae may develop resistance to ampicillin or other $\beta$-lactam antimicrobials: amino acid substitutions in penicillin-binding protein 3 (PBP3) also confer low-level resistance to $\beta$-lactam antimicrobials. Recent reports suggest that PBP3 amino acid substitutions are increasing among isolates of $H$. influenzae in Europe, resulting in increased occurrences of $\beta$-lactamase-negative, ampicillin-resistant (BLNAR) isolates [17-19]. Haemophilus influenzae resistance is low against all agents in this study with the exception of ampicillin, against which $13.7 \%$ resistance was reported. Previous studies have shown that changes to PBP3 can result in large-scale increases in imipenem resistance in $H$. influenzae [20]. Although no imipenem-resistant $H$. influenzae isolates were identified in this study, $\beta$-lactamase-negative isolates with an imipenem MIC of $4 \mathrm{mg} / \mathrm{L}$ have been identified. These indicate that BLNAR $H$. influenzae are most likely present among the isolates collected during this study; the 
MIC distribution of imipenem could possibly be used as an indicator of the prevalence of BLNAR H. influenzae in Europe.

MRSA prevalence is typically highest in southern and western Europe, with lower rates seen in northern Europe [21]. This trend generally holds true in the current study. National MRSA prevalence varied widely in this study, ranging from $0 \%$ in Norway and The Netherlands to $48.8 \%$ in Greece and $58.3 \%$ in Poland. Large variations in national MRSA prevalence across Europe have previously been reported. Sader et al. [22] noted MRSA occurrence ranging from 2.1\% in Sweden to $54.7 \%$ in Ireland as part of the SENTRY study in 2005. Similarly, Tiemersma et al. [21] described MRSA levels between $0.5 \%$ in Iceland and $44.0 \%$ in Greece between 1999 and 2002. The relative prevalence of MRSA isolates is still very low in several European countries, which may result in large year-to-year fluctuations in MRSA levels [21]. Regardless of their country of origin, MRSA isolates were highly $(\geq 99.9 \%)$ susceptible to tigecycline, linezolid and vancomycin in this European study.

The numbers of VRE by country were insufficient in the current study to draw meaningful conclusions regarding local changes in distribution. However, levels appear to be stable across Europe: Sader et al. [22] noted vancomycin-resistant $E$. faecalis and E. faecium levels of $0.9 \%$ and $17.9 \%$, respectively in 2005 , whilst $1.2 \%$ of $E$. faecalis and $15.7 \%$ of $E$. faecium isolates were vancomycin-resistant in the current study. Enterococci are often intrinsically resistant to many clinically important antimicrobial agents and are commonly implicated in nosocomial infections and bacteraemia [23]. Tigecycline had a $\mathrm{MIC}_{90}$ of $0.12 \mathrm{mg} / \mathrm{L}$ against vancomycin- 
resistant $E$. faecium, making it the most active agent against this pathogen in this study.

The frequency of occurrence of penicillin resistance among S. pneumoniae also appears to be stable across Europe. Streptococcus pneumoniae is an important pathogen in respiratory tract pathogens worldwide, with therapeutic options often limited by the presence of resistant or MDR strains [24]. Isolates of PRSP account for $9.3 \%$ of S. pneumoniae in the current study, only slightly lower than the $12.1 \%$ reported across Europe by Reinert et al. [25] between 2001 and 2003. Reinert et al. [25] also described $24.6 \%$ of $S$. pneumoniae isolates as being penicillin nonsusceptible, similar to the $27.6 \%$ non-susceptibility seen in the current study. The lowest PRSP $\mathrm{MIC}_{90}$ seen in this study was for tigecycline $(0.12 \mathrm{mg} / \mathrm{L})$.

Surveillance studies are crucial elements in monitoring trends in antimicrobial resistance on local, national and global scales today. The information gathered during these studies is essential in preparing evidence-based guidelines for the treatment of bacterial infections $[25,26]$. TEST is one such study, designed to longitudinally monitor the susceptibilities of numerous key pathogens to tigecycline (plus several comparators) on a global scale. Previous reports from the TEST study have indicated good in vitro activity for tigecycline against most of the pathogens in the TEST panel [27]. In the current study, which includes data collected from 24 European countries over a 4-year period, tigecycline was highly active in vitro against most of the pathogens monitored, including MDR pathogens. This activity was stable over the study period, whilst increasing resistance was noted for several comparator agents during the same period. Tigecycline is approved for the treatment 
of intra-abdominal and complicated skin and soft-tissue infections and retains potential to be a valuable part of the armamentarium used to combat MDR pathogens.

Acknowledgments: Thanks are extended to the many investigators throughout Europe who contributed isolates to the TEST study. The authors also extend thanks to the staff of International Health Management Associates, Inc. (Schaumburg, IL) for their co-ordination of the TEST study and database. Micron Research Ltd., UK provided data analysis support, whilst Dr Rod Taylor (of Micron Research Ltd., Chatteris, UK) assisted in the writing of this manuscript.

Funding: The TEST study was funded by Wyeth Pharmaceuticals. Wyeth Pharmaceuticals also funded the writing support provided by Micron Research Ltd., UK.

Competing interests: NN-L has lectured at educational meetings sponsored by Wyeth and other pharmaceutical companies and has received sponsorship from Wyeth to attend an educational meeting. MJD is an employee of Wyeth Pharmaceuticals.

Ethical approval: Not required. 


\section{References}

[1] Carmeli Y. Strategies for managing today's infections. Clin Microbiol Infect 2008;14(Suppl 3):22-31.

[2] Chastre J. Evolving problems with resistant pathogens. Clin Microbiol Infect 2008;14(Suppl 3):3-14.

[3] Gupta V. Metallo beta lactamases in Pseudomonas aeruginosa and Acinetobacter species. Expert Opin Investig Drugs 2008;17:131-43.

[4] Bergeron J, Ammirati M, Danley D, James L, Norcia M, Retsema J, et al. Glycylcyclines bind to the high-affinity tetracycline ribosomal binding site and evade Tet(M)- and Tet(O)-mediated ribosomal protection. Antimicrob Agents Chemother 1996;40:2226-8.

[5] Fritsche TR, Sader HS, Stilwell MG, Dowzicky MJ, Jones RN. Potency and spectrum of tigecycline tested against an international collection of bacterial pathogens associated with skin and soft tissue infections (2000-2004). Diagn Microbiol Infect Dis 2005;52:195-201.

[6] Townsend ML, Pound MW, Drew RH. Tigecycline in the treatment of complicated intra-abdominal and complicated skin and skin structure infections. Ther Clin Risk Manag 2007;3:1059-70.

[7] Wyeth Pharmaceuticals Inc. Tygacil ${ }^{\circledR}$ product insert. Philadelphia, PA: Wyeth Pharmaceuticals Inc; 2007. http://www.wyeth.com/hcp/tygacil [accessed 6 August 2008].

[8] Rodloff AC, Leclercq R, Debbia EA, Cantón R, Oppenheim BA, Dowzicky MJ. Comparative analysis of antimicrobial susceptibility among organisms from France, Germany, Italy, Spain and the UK as part of the Tigecycline Evaluation and Surveillance Trial. Clin Microbiol Infect 2008;14:307-14. 
[9] National Committee for Clinical Laboratory Standards. Methods for dilution antimicrobial susceptibility tests for bacteria that grow aerobically; approved standard. 6th ed. Document M7-A6. Wayne, PA: NCCLS; 2003.

[10] Clinical and Laboratory Standards Institute. Performance standards for antimicrobial susceptibility testing. 16th ed. Document M100-S16. Wayne, PA: CLSI; 2006.

[11] Turner PJ, Greenhalgh JM; MYSTIC Study Group (Europe). The activity of meropenem and comparators against Acinetobacter strains isolated from European hospitals, 1997-2000. Clin Microbiol Infect 2003;9:563-67.

[12] Van Looveren M, Goossens H; ARPAC Steering Group. Antimicrobial resistance of Acinetobacter spp. in Europe. Clin Microbiol Infect 2004;10:684704.

[13] Vasilev K, Reshedko G, Orasan R, Sanchez M, Teras J, Babinchak T, et al. A Phase 3, open-label, non-comparative study of tigecycline in the treatment of patients with selected serious infections due to resistant Gram-negative organisms including Enterobacter species, Acinetobacter baumannii and Klebsiella pneumoniae. J Antimicrob Chemother 2008;62(Suppl 1):i29-40.

[14] Wenzel RP, Sahm DF, Thornsberry C, Draghi CD, Jones ME. Karlowsky JA. In vitro susceptibilities of gram-negative bacteria isolated from hospitalized patients in four European countries, Canada, and the United States in 2000-2001 to expanded-spectrum cephalosporins and comparator antimicrobials: implications for therapy. Antimicrob Agents Chemother 2003;47:3089-98.

[15] Cantón R, Novais A, Valverde A, Machado E, Peixe L, Baquero F, et al. Prevalence and spread of extended-spectrum $\beta$-lactamase-producing Enterobacteriaceae in Europe. Clin Microbiol Infect 2008;14(Suppl 1):144-53. 
[16] Coque TM, Novais A, Carattoli A, Poirel L, Pitout J, Peixe L, et al.

Dissemination of clonally related Escherichia coli strains expressing extendedspectrum $\beta$-lactamase CTX-M-15. Emerg Infect Dis 2008;14:195-200.

[17] Dabernat H, Delmas C, Seguy M, Pelissier R, Faucon G, Bennamani S, et al. Diversity of $\beta$-lactam resistance-conferring amino acid substitutions in penicillinbinding protein 3 of Haemophilus influenzae. Antimicrob Agents Chemother 2002;46:2208-18.

[18] Fluit AC, Florijn A, Verhoef J, Milatovic D. Susceptibility of European $\beta$ lactamase-positive and -negative Haemophilus influenzae isolates from the periods 1997/1998 and 2002/2003. J Antimicrob Chemother 2005;56:133-8.

[19] García-Cobos S, Campos J, Lázaro E, Román F, Cercenado E, Garciá-Rey C, et al. Ampicillin-resistant non- $\beta$-lactamase-producing Haemophilus influenzae in Spain: recent emergence of clonal isolates with increased resistance to cefotaxime and cefixime. Antimicrob Agents Chemother 2007;51:2564-73.

[20] Osaki Y, Sanbongi Y, Ishikawa M, Kataoka H, Suzuki T, Maeda K, et al. Genetic approach to study the relationship between penicillin-binding protein 3 mutations and Haemophilus influenzae $\beta$-lactam resistance by using site-directed mutagenesis and gene recombinants. Antimicrob Agents Chemother 2005;49:2834-9.

[21] Tiemersma EW, Bronzwaer SL, Lyytikäinen O, Degener JE, Schrijnemakers P, Bruinsma N, et al. Methicillin-resistant Staphylococcus aureus in Europe, 1999-2002. Emerg Infect Dis 2004;10:1627-34.

[22] Sader HS, Watters AA, Fritsche TR, Jones RN. Daptomycin antimicrobial activity tested against methicillin-resistant staphylococci and vancomycin- 
resistant enterococci isolated in European medical centres (2005). BMC Infect Dis $2007 ; 7: 9$.

[23] Chou YY, Lin TY, Lin JC, Wang NC, Peng NY, Chang FY. Vancomycinresistant enterococcal bacteremia: comparison of clinical features and outcome between Enterococcus faecium and Enterococcus faecalis. J Microbiol Immunol Infect 2008;41:124-9.

[24] Van Eldere J, Mera RM, Miller LA, Poupard JA, Amrine-Madsen H. Risk factors for development of multiple-class resistance to Streptococcus pneumoniae strains in Belgium over a 10-year period: antimicrobial consumption, population density, and geographic location. Antimicrob Agents Chemother $2007 ; 51: 3491-7$

[25] Reinert RR, Reinert S, van der Linden M, Cil MY, Al-Lahham A, Appelbaum P. Antimicrobial susceptibility of Streptococcus pneumoniae in eight European countries from 2001 to 2003. Antimicrob Agents Chemother 2005;49:2903-13. [26] Jones ME, Draghi DC, Thornsberry C, Karlowsky JA, Sahm DF, Wenzel RP. Emerging resistance among bacterial pathogens in the intensive care unit-a European and North American Surveillance study (2000-2002). Ann Clin Microbiol Antimicrob 2004;3:14.

[27] Hoban DJ, Bouchillon SK, Johnson BM, Johnson JL, Dowzicky MJ; Tigecycline Evaluation and Surveillance Trial (TEST Program) Group. In vitro activity of tigecycline against 6792 Gram-negative and Gram-positive clinical isolates from the global Tigecycline Evaluation and Surveillance Trial (TEST Program, 2004). Diagn Microbiol Infect Dis 2005;52:215-27. 
Table 1

Minimum inhibitory concentrations (MICs) and antimicrobial susceptibility of pooled Gram-negative and Gram-positive organisms

\begin{tabular}{|c|c|c|c|c|c|c|c|}
\hline \multirow[t]{2}{*}{ Organism } & \multirow[t]{2}{*}{$N$} & \multicolumn{3}{|c|}{$\mathrm{MIC}(\mathrm{mg} / \mathrm{L})$} & \multicolumn{3}{|c|}{ Susceptibility } \\
\hline & & $\mathrm{MIC}_{50}$ & $\mathrm{MIC}_{90}$ & Range & $\% \mathrm{~S}$ & $\% \mathrm{R}$ & $\Delta R(\%)^{a}$ \\
\hline \multicolumn{8}{|c|}{ Gram-negative 16760} \\
\hline \multicolumn{8}{|c|}{ Acinetobacter baumannii } \\
\hline Tigecycline & 1560 & 0.25 & 1 & $\leq 0.008-16$ & $\mathrm{~N} / \mathrm{A}$ & $\mathrm{N} / \mathrm{A}$ & \\
\hline Minocycline & 1560 & $\leq 0.5$ & 4 & $\leq 0.5$ to $\geq 32$ & 94.2 & 2.1 & -2.0 \\
\hline Ampicillin & 1560 & $\geq 64$ & $\geq 64$ & $\leq 0.5$ to $\geq 64$ & N/A & $\mathrm{N} / \mathrm{A}$ & - \\
\hline AMC & 1560 & 32 & $\geq 64$ & 0.25 to $\geq 64$ & $\mathrm{~N} / \mathrm{A}$ & $\mathrm{N} / \mathrm{A}$ & - \\
\hline PIP/TAZ & 1560 & 16 & $\geq 256$ & $\leq 0.06$ to $\geq 256$ & 56.0 & 33.2 & 0.0 \\
\hline Ceftazidime & 1560 & $\leq 8$ & $\geq 64$ & $\leq 8$ to $\geq 64$ & 52.3 & 39.5 & -2.4 \\
\hline Ceftriaxone & 1560 & 16 & $\geq 128$ & $\leq 0.06$ to $\geq 128$ & 31.9 & 42.8 & -1.3 \\
\hline Cefepime & 1560 & 8 & $\geq 64$ & $\leq 0.5$ to $\geq 64$ & 56.6 & 28.7 & -0.4 \\
\hline Imipenem & 919 & 0.5 & 16 & $\leq 0.06$ to $\geq 32$ & 85.2 & 12.6 & -13.0 \\
\hline Meropenem & 641 & 1 & 16 & $\leq 0.06$ to $\geq 32$ & 68.5 & 23.4 & -8.2 \\
\hline Levofloxacin & 1560 & 2 & $\geq 16$ & $\leq 0.008$ to $\geq 16$ & 55.0 & 32.1 & -4.7 \\
\hline Amikacin & 1560 & 4 & $\geq 128$ & $\leq 0.5$ to $\geq 128$ & 71.4 & 23.7 & 1.0 \\
\hline \multicolumn{8}{|c|}{ Enterobacter aerogenes } \\
\hline Tigecycline & 682 & 0.5 & 2 & $0.03-8$ & 88.7 & 2.9 & -2.4 \\
\hline Minocycline & 682 & 2 & 8 & $\leq 0.5$ to $\geq 32$ & 81.2 & 7.3 & 3.8 \\
\hline Ampicillin & 682 & $\geq 64$ & $\geq 64$ & 1 to $\geq 64$ & 0.1 & 95.2 & -4.1 \\
\hline AMC & 682 & $\geq 64$ & $\geq 64$ & $\leq 0.12$ to $\geq 64$ & 2.8 & 93.1 & 4.3 \\
\hline PIP/TAZ & 682 & 4 & 64 & $\leq 0.06$ to $\geq 256$ & 74.5 & 7.6 & 1.2 \\
\hline Ceftazidime & 682 & $\leq 8$ & $\geq 64$ & $\leq 8$ to $\geq 64$ & 61.1 & 31.4 & -10.6 \\
\hline Ceftriaxone & 682 & 0.5 & 64 & $\leq 0.06$ to $\geq 128$ & 74.9 & 10.3 & -0.9 \\
\hline Cefepime & 682 & $\leq 0.5$ & 8 & $\leq 0.5$ to $\geq 64$ & 93.5 & 4.3 & -5.9 \\
\hline Imipenem & 443 & 0.5 & 2 & $\leq 0.06-8$ & 99.5 & 0.0 & 0.0 \\
\hline Meropenem & 239 & $\leq 0.06$ & 0.25 & $\leq 0.06-16$ & 97.9 & 0.4 & 0.0 \\
\hline Levofloxacin & 682 & 0.06 & $\geq 16$ & $\leq 0.008$ to $\geq 16$ & 74.3 & 22.4 & 3.3 \\
\hline Amikacin & 682 & 2 & 8 & $\leq 0.5$ to $\geq 128$ & 97.4 & 1.3 & 0.9 \\
\hline
\end{tabular}




\begin{tabular}{|c|c|c|c|c|c|c|c|}
\hline \multicolumn{8}{|c|}{ Enterobacter cloacae } \\
\hline Tigecycline & 2364 & 0.5 & 2 & $0.06-8$ & 87.3 & 5.6 & -2.4 \\
\hline Minocycline & 2364 & 4 & 8 & $\leq 0.5$ to $\geq 32$ & 78.4 & 9.9 & 5.8 \\
\hline Ampicillin & 2364 & $\geq 64$ & $\geq 64$ & 2 to $\geq 64$ & 0.8 & 91.9 & -2.2 \\
\hline AMC & 2364 & $\geq 64$ & $\geq 64$ & 0.25 to $\geq 64$ & 1.6 & 96.7 & -1.6 \\
\hline PIP/TAZ & 2364 & 4 & 128 & $\leq 0.06$ to $\geq 256$ & 69.9 & 17.8 & 4.7 \\
\hline Ceftazidime & 2364 & $\leq 8$ & $\geq 64$ & $\leq 8$ to $\geq 64$ & 64.0 & 29.5 & 3.3 \\
\hline Ceftriaxone & 2364 & 0.5 & $\geq 128$ & $\leq 0.06$ to $\geq 128$ & 67.2 & 21.8 & 4.2 \\
\hline Cefepime & 2364 & $\leq 0.5$ & 8 & $\leq 0.5$ to $\geq 64$ & 92.9 & 5.0 & -0.5 \\
\hline Imipenem & 1422 & 0.5 & 1 & $\leq 0.06$ to $\geq 32$ & 99.3 & 0.4 & 0.6 \\
\hline Meropenem & 942 & $\leq 0.06$ & 0.25 & $\leq 0.06$ to $\geq 32$ & 99.2 & 0.4 & 0.4 \\
\hline Levofloxacin & 2364 & 0.06 & 8 & $\leq 0.008$ to $\geq 16$ & 85.8 & 12.1 & 6.3 \\
\hline Amikacin & 2364 & 2 & 4 & $\leq 0.5$ to $\geq 128$ & 98.4 & 1.1 & -0.5 \\
\hline \multicolumn{8}{|c|}{ Escherichia coli } \\
\hline Tigecycline & 3403 & 0.12 & 0.5 & $\leq 0.008-8$ & 99.2 & $0.03^{b}$ & 0.0 \\
\hline Minocycline & 3403 & 1 & 16 & $\leq 0.5$ to $\geq 32$ & 79.5 & 10.3 & 6.6 \\
\hline Ampicillin & 3403 & $\geq 64$ & $\geq 64$ & $\leq 0.5$ to $\geq 64$ & 39.8 & 59.4 & 4.2 \\
\hline AMC & 3403 & 8 & 32 & 0.5 to $\geq 64$ & 69.6 & 12.3 & 0.6 \\
\hline PIP/TAZ & 3403 & 1 & 16 & $\leq 0.06$ to $\geq 256$ & 92.0 & 4.3 & 1.3 \\
\hline Ceftazidime & 3403 & $\leq 8$ & $\leq 8$ & $\leq 8$ to $\geq 64$ & 93.4 & 4.5 & 2.0 \\
\hline Ceftriaxone & 3403 & $\leq 0.06$ & 16 & $\leq 0.06$ to $\geq 128$ & 89.3 & 9.1 & 3.0 \\
\hline Cefepime & 3403 & $\leq 0.5$ & 4 & $\leq 0.5$ to $\geq 64$ & 92.7 & 5.7 & 3.5 \\
\hline Imipenem & 2093 & 0.25 & 0.5 & $\leq 0.06$ to $\geq 32$ & 99.9 & 0.1 & 0.0 \\
\hline Meropenem & 1310 & $\leq 0.06$ & $\leq 0.06$ & $\leq 0.06-8$ & 99.8 & 0.0 & 0.0 \\
\hline Levofloxacin & 3403 & 0.03 & $\geq 16$ & $\leq 0.008$ to $\geq 16$ & 75.1 & 21.6 & 5.8 \\
\hline Amikacin & 3403 & 2 & 8 & $\leq 0.5$ to $\geq 128$ & 98.6 & 0.7 & 0.1 \\
\hline \multicolumn{8}{|c|}{ Haemophilus influenzae } \\
\hline Tigecycline & 1634 & 0.12 & 0.5 & $\leq 0.008-2$ & N/A & $\mathrm{N} / \mathrm{A}$ & - \\
\hline Minocycline & 1634 & $\leq 0.5$ & 1 & $\leq 0.5$ to $\geq 32$ & 97.3 & 0.7 & -0.5 \\
\hline Ampicillin & 1634 & $\leq 0.5$ & 16 & $\leq 0.5$ to $\geq 64$ & 83.6 & 13.7 & -0.4 \\
\hline AMC & 1634 & 0.5 & 1 & $\leq 0.12-32$ & 99.6 & 0.4 & 0.2 \\
\hline PIP/TAZ & 1634 & $\leq 0.06$ & $\leq 0.06$ & $\leq 0.06-16$ & 99.8 & 0.2 & 0.0 \\
\hline Ceftriaxone & 1634 & $\leq 0.06$ & $\leq 0.06$ & $\leq 0.06-32$ & 99.9 & $\mathrm{~N} / \mathrm{A}$ & - \\
\hline
\end{tabular}




\begin{tabular}{|c|c|c|c|c|c|c|c|}
\hline Cefepime & 1634 & $\leq 0.5$ & $\leq 0.5$ & $\leq 0.5-32$ & 99.0 & $\mathrm{~N} / \mathrm{A}$ & - \\
\hline Imipenem & 993 & 0.25 & 1 & $\leq 0.06-4$ & 100 & $\mathrm{~N} / \mathrm{A}$ & - \\
\hline Meropenem & 641 & $\leq 0.06$ & 0.12 & $\leq 0.06-0.5$ & 100 & $\mathrm{~N} / \mathrm{A}$ & - \\
\hline Levofloxacin & 1634 & 0.015 & 0.03 & $\leq 0.008-1$ & 100 & N/A & - \\
\hline Amikacin & 1634 & 4 & 8 & $\leq 0.5-64$ & $N / A$ & N/A & - \\
\hline \multicolumn{7}{|c|}{ Klebsiella oxytoca } & \\
\hline Tigecycline & 922 & 0.25 & 1 & $\leq 0.008-8$ & 93.5 & 1.8 & -0.2 \\
\hline Minocycline & 922 & 1 & 8 & $\leq 0.5$ to $\geq 32$ & 88.3 & 5.3 & 6.2 \\
\hline Ampicillin & 922 & $\geq 64$ & $\geq 64$ & 1 to $\geq 64$ & 1.1 & 87.7 & 3.6 \\
\hline AMC & 922 & 4 & 32 & 0.5 to $\geq 64$ & 79.3 & 13.3 & 0.5 \\
\hline PIP/TAZ & 922 & 1 & $\geq 256$ & $\leq 0.06$ to $\geq 256$ & 83.6 & 14.4 & -1.7 \\
\hline Ceftazidime & 922 & $\leq 8$ & $\leq 8$ & $\leq 8$ to $\geq 64$ & 94.3 & 3.4 & -1.9 \\
\hline Ceftriaxone & 922 & $\leq 0.06$ & 8 & $\leq 0.06$ to $\geq 128$ & 90.1 & 4.8 & 0.5 \\
\hline Cefepime & 922 & $\leq 0.5$ & 2 & $\leq 0.5$ to $\geq 64$ & 96.2 & 2.3 & -2.3 \\
\hline Imipenem & 552 & 0.25 & 0.5 & $\leq 0.06-8$ & 99.8 & 0.0 & 0.0 \\
\hline Meropenem & 370 & $\leq 0.06$ & 0.12 & $\leq 0.06-8$ & 99.7 & 0.0 & 0.0 \\
\hline Levofloxacin & 922 & 0.06 & 1 & $\leq 0.008$ to $\geq 16$ & 93.3 & 4.9 & 1.2 \\
\hline Amikacin & 922 & 2 & 4 & $\leq 0.5$ to $\geq 128$ & 98.7 & 0.8 & 0.0 \\
\hline \multicolumn{8}{|c|}{ Klebsiella pneumoniae } \\
\hline Tigecycline & 2331 & 0.5 & 2 & $0.015-16$ & 88.0 & 4.7 & -5.4 \\
\hline Minocycline & 2331 & 2 & 16 & $\leq 0.5$ to $\geq 32$ & 75.6 & 16.0 & 4.4 \\
\hline Ampicillin & 2331 & $\geq 64$ & $\geq 64$ & $\leq 0.5$ to $\geq 64$ & 0.6 & 86.2 & 2.8 \\
\hline AMC & 2331 & 4 & 32 & 0.5 to $\geq 64$ & 72.7 & 15.0 & 3.0 \\
\hline PIP/TAZ & 2331 & 2 & 128 & 0.12 to $\geq 256$ & 84.4 & 10.3 & 2.8 \\
\hline Ceftazidime & 2331 & $\leq 8$ & $\geq 64$ & $\leq 8$ to $\geq 64$ & 82.4 & 14.8 & 2.1 \\
\hline Ceftriaxone & 2331 & $\leq 0.06$ & $\geq 128$ & $\leq 0.06$ to $\geq 128$ & 82.2 & 13.8 & 5.4 \\
\hline Cefepime & 2331 & $\leq 0.5$ & 16 & $\leq 0.5$ to $\geq 64$ & 88.8 & 8.5 & 5.0 \\
\hline Imipenem & 1403 & 0.25 & 0.5 & $\leq 0.06$ to $\geq 32$ & 99.7 & 0.3 & 0.0 \\
\hline Meropenem & 928 & $\leq 0.06$ & 0.25 & $\leq 0.06$ to $\geq 32$ & 98.3 & 1.2 & -1.7 \\
\hline Levofloxacin & 2331 & 0.06 & 8 & $\leq 0.008$ to $\geq 16$ & 85.7 & 10.9 & 6.9 \\
\hline Amikacin & 2331 & 2 & 8 & $\leq 0.5$ to $\geq 128$ & 96.9 & 1.9 & 0.7 \\
\hline \multicolumn{8}{|c|}{ Pseudomonas aeruginosa } \\
\hline Tigecycline & 2653 & 8 & $\geq 32$ & 0.06 to $\geq 32$ & N/A & N/A & - \\
\hline
\end{tabular}




\begin{tabular}{|c|c|c|c|c|c|c|c|}
\hline Minocycline & 2653 & $\geq 32$ & $\geq 32$ & $\leq 0.5$ to $\geq 32$ & 5.9 & 77.6 & -0.8 \\
\hline Ampicillin & 2653 & $\geq 64$ & $\geq 64$ & $\leq 0.5$ to $\geq 64$ & N/A & $\mathrm{N} / \mathrm{A}$ & - \\
\hline AMC & 2653 & $\geq 64$ & $\geq 64$ & 0.5 to $\geq 64$ & $\mathrm{~N} / \mathrm{A}$ & $\mathrm{N} / \mathrm{A}$ & - \\
\hline PIP/TAZ & 2653 & 4 & 128 & $\leq 0.06$ to $\geq 256$ & 86.8 & 13.2 & 3.1 \\
\hline Ceftazidime & 2653 & $\leq 8$ & 32 & $\leq 8$ to $\geq 64$ & 76.6 & 14.8 & 1.8 \\
\hline Ceftriaxone & 2653 & 64 & $\geq 128$ & $\leq 0.06$ to $\geq 128$ & 15.3 & 55.9 & -9.7 \\
\hline Cefepime & 2653 & 4 & 32 & $\leq 0.5$ to $\geq 64$ & 76.4 & 12.2 & -1.7 \\
\hline Imipenem & 1624 & 1 & 8 & $\leq 0.06$ to $\geq 32$ & 82.6 & 9.7 & -4.2 \\
\hline Meropenem & 1029 & 1 & 16 & $\leq 0.06$ to $\geq 32$ & 79.4 & 13.8 & -8.4 \\
\hline Levofloxacin & 2653 & 1 & $\geq 16$ & $\leq 0.008$ to $\geq 16$ & 66.2 & 27.1 & 0.0 \\
\hline Amikacin & 2653 & 4 & 16 & $\leq 0.5$ to $\geq 128$ & 92.8 & 4.2 & 0.1 \\
\hline \multicolumn{8}{|c|}{ Serratia marcescens } \\
\hline Tigecycline & 1211 & 1 & 2 & $0.06-16$ & 81.6 & 3.2 & -1.3 \\
\hline Minocycline & 1211 & 4 & 8 & $\leq 0.5$ to $\geq 32$ & 80.8 & 4.8 & 6.0 \\
\hline Ampicillin & 1210 & $\geq 64$ & $\geq 64$ & 2 to $\geq 64$ & 0.5 & 91.3 & -4.7 \\
\hline AMC & 1211 & $\geq 64$ & $\geq 64$ & 2 to $\geq 64$ & 1.0 & 96.9 & -2.3 \\
\hline PIP/TAZ & 1211 & 2 & 32 & $\leq 0.06$ to $\geq 256$ & 89.5 & 3.3 & 2.2 \\
\hline Ceftazidime & 1211 & $\leq 8$ & $\leq 8$ & $\leq 8$ to $\geq 64$ & 92.3 & 6.1 & 1.5 \\
\hline Ceftriaxone & 1211 & 0.25 & 16 & $\leq 0.06$ to $\geq 128$ & 89.4 & 4.6 & 0.9 \\
\hline Cefepime & 1211 & $\leq 0.5$ & 1 & $\leq 0.5$ to $\geq 64$ & 97.3 & 2.2 & 0.3 \\
\hline Imipenem & 729 & 0.5 & 1 & $\leq 0.06$ to $\geq 32$ & 98.9 & 0.7 & 0.0 \\
\hline Meropenem & 482 & $\leq 0.06$ & 0.25 & $\leq 0.06$ to $\geq 32$ & 97.9 & 1.5 & 0.5 \\
\hline Levofloxacin & 1211 & 0.12 & 2 & $\leq 0.008$ to $\geq 16$ & 93.0 & 4.0 & 1.9 \\
\hline Amikacin & 1211 & 2 & 8 & $\leq 0.5$ to $\geq 128$ & 97.9 & 1.1 & -0.3 \\
\hline Gram-positive & \multicolumn{7}{|l|}{7988} \\
\hline \multicolumn{8}{|c|}{ Enterococcus faecalis } \\
\hline Tigecycline & 1433 & 0.12 & 0.25 & $\leq 0.008-0.5$ & N/A & $\mathrm{N} / \mathrm{A}$ & - \\
\hline Minocycline & 1433 & 8 & $\geq 16$ & $\leq 0.25$ to $\geq 16$ & 38.0 & 27.8 & 18.3 \\
\hline Penicillin & 1433 & 2 & 4 & $\leq 0.06$ to $\geq 16$ & 99.9 & 0.1 & -0.3 \\
\hline Ampicillin & 1433 & 1 & 2 & $\leq 0.06$ to $\geq 32$ & 99.9 & 0.1 & -0.3 \\
\hline AMC & 1433 & 0.5 & 1 & $\leq 0.03$ to $\geq 16$ & $\mathrm{~N} / \mathrm{A}$ & $\mathrm{N} / \mathrm{A}$ & - \\
\hline PIP/TAZ & 1433 & 2 & 8 & $\leq 0.25$ to $\geq 32$ & $\mathrm{~N} / \mathrm{A}$ & $\mathrm{N} / \mathrm{A}$ & - \\
\hline Ceftriaxone & 1433 & $\geq 128$ & $\geq 128$ & $\leq 0.03$ to $\geq 128$ & N/A & $\mathrm{N} / \mathrm{A}$ & - \\
\hline
\end{tabular}




\begin{tabular}{llllllll}
\hline Imipenem & 852 & 1 & 4 & $\leq 0.12$ to $\geq 32$ & N/A & N/A & - \\
Meropenem & 581 & 4 & 8 & $\leq 0.12$ to $\geq 32$ & N/A & N/A & - \\
Levofloxacin & 1433 & 1 & 32 & $\leq 0.06$ to $\geq 64$ & 69.3 & 29.4 & -4.4 \\
Linezolid & 1433 & 2 & 2 & $\leq 0.5-4$ & 97.8 & 0.0 & 0.0 \\
Vancomycin & 1433 & 1 & 2 & $\leq 0.12$ to $\geq 64$ & 98.7 & 1.2 & -0.9
\end{tabular}

Enterococcus faecium

$\begin{array}{llllllll}\text { Tigecycline } & 491 & 0.06 & 0.12 & \leq 0.008-0.25 & \mathrm{~N} / \mathrm{A} & \mathrm{N} / \mathrm{A} & - \\ \text { Minocycline } & 491 & \leq 0.25 & \geq 16 & \leq 0.25 \text { to } \geq 16 & 72.9 & 14.9 & 8.4 \\ \text { Penicillin } & 491 & \geq 16 & \geq 16 & \leq 0.06 \text { to } \geq 16 & 14.9 & 85.1 & 10.3 \\ \text { Ampicillin } & 491 & \geq 32 & \geq 32 & \leq 0.06 \text { to } \geq 32 & 18.1 & 81.9 & 16.1 \\ \text { AMC } & 491 & \geq 16 & \geq 16 & \leq 0.03 \text { to } \geq 16 & \mathrm{~N} / \mathrm{A} & \mathrm{N} / \mathrm{A} & - \\ \text { PIP/TAZ } & 491 & \geq 32 & \geq 32 & \leq 0.25 \text { to } \geq 32 & \mathrm{~N} / \mathrm{A} & \mathrm{N} / \mathrm{A} & - \\ \text { Ceftriaxone } & 491 & \geq 128 & \geq 128 & \leq 0.03 \text { to } \geq 128 & \mathrm{~N} / \mathrm{A} & \mathrm{N} / \mathrm{A} & - \\ \text { Imipenem } & 308 & \geq 32 & \geq 32 & \leq 0.12 \text { to } \geq 32 & \mathrm{~N} / \mathrm{A} & \mathrm{N} / \mathrm{A} & - \\ \text { Meropenem } & 183 & \geq 32 & \geq 32 & \leq 0.12 \text { to } \geq 32 & \mathrm{~N} / \mathrm{A} & \mathrm{N} / \mathrm{A} & - \\ \text { Levofloxacin } & 491 & \geq 64 & \geq 64 & 0.25 \text { to } \geq 64 & 20.6 & 75.2 & 11.2 \\ \text { Linezolid } & 491 & 2 & 2 & \leq 0.5-4 & 91.6 & 0.0 & 0.0 \\ \text { Vancomycin } & 491 & 1 & \geq 64 & \leq 0.12 \text { to } \geq 64 & 83.1 & 15.7 & 3.6\end{array}$

Staphylococcus aureus

$\begin{array}{llllllll}\text { Tigecycline } & 3218 & 0.12 & 0.25 & \leq 0.008-1 & 99.97^{\mathrm{b}} & 0.03^{\mathrm{b}} & 0.0 \\ \text { Minocycline } & 3218 & \leq 0.25 & 0.5 & \leq 0.25 \text { to } \geq 16 & 98.7 & 0.2 & 0.3 \\ \text { Penicillin } & 3218 & 8 & \geq 16 & \leq 0.06 \text { to } \geq 16 & 14.2 & 85.8 & -3.0 \\ \text { Ampicillin } & 3218 & 8 & \geq 32 & \leq 0.06 \text { to } \geq 32 & 16.7 & 83.3 & -2.6 \\ \text { AMC } & 3218 & 1 & \geq 16 & \leq 0.03 \text { to } \geq 16 & 82.8 & 17.2 & -3.4 \\ \text { PIP/TAZ } & 3218 & 1 & \geq 32 & \leq 0.25 \text { to } \geq 32 & 84.3 & 15.7 & -3.7 \\ \text { Ceftriaxone } & 3218 & 4 & \geq 128 & \leq 0.03 \text { to } \geq 128 & 77.9 & 14.2 & -5.4 \\ \text { Imipenem } & 1807 & 0.25 & 8 & \leq 0.12 \text { to } \geq 32 & 89.9 & 9.4 & -1.2 \\ \text { Meropenem } & 1411 & \leq 0.12 & 8 & \leq 0.12 \text { to } \geq 32 & 88.6 & 8.9 & -7.2 \\ \text { Levofloxacin } & 3218 & 0.25 & 16 & \leq 0.06 \text { to } \geq 64 & 74.2 & 24.1 & -0.2 \\ \text { Linezolid } & 3218 & 2 & 4 & \leq 0.5-4 & 100 & \mathrm{~N} / \mathrm{A} & - \\ \text { Vancomycin } & 3218 & 1 & 1 & \leq 0.12-2 & 100 & 0.0 & 0.0\end{array}$

Streptococcus agalactiae

$\begin{array}{llllllll}\text { Tigecycline } & 1244 & 0.03 & 0.12 & \leq 0.008-0.5 & 99.9 & 0.0 & 0.0\end{array}$ 


\begin{tabular}{|c|c|c|c|c|c|c|c|}
\hline Minocycline & 1244 & 8 & $\geq 16$ & $\leq 0.25$ to $\geq 16$ & 20.9 & 70.6 & 14.5 \\
\hline Penicillin & 1244 & $\leq 0.06$ & 0.12 & $\leq 0.06-2$ & 99.8 & $N / A$ & - \\
\hline Ampicillin & 1244 & 0.12 & 0.12 & $\leq 0.06-1$ & 99.8 & $N / A$ & - \\
\hline AMC & 1244 & 0.06 & 0.12 & $\leq 0.03-0.5$ & $\mathrm{~N} / \mathrm{A}$ & $N / A$ & - \\
\hline PIP/TAZ & 1244 & $\leq 0.25$ & $\leq 0.25$ & $\leq 0.25-2$ & $N / A$ & $\mathrm{~N} / \mathrm{A}$ & - \\
\hline Ceftriaxone & 1244 & 0.06 & 0.12 & $\leq 0.03-8$ & 99.8 & $\mathrm{~N} / \mathrm{A}$ & - \\
\hline Imipenem & 620 & $\leq 0.12$ & 0.25 & $\leq 0.12-8$ & $N / A$ & $N / A$ & \\
\hline Meropenem & 624 & $\leq 0.12$ & $\leq 0.12$ & $\leq 0.12-4$ & 99.7 & $N / A$ & - \\
\hline Levofloxacin & 1244 & 0.5 & 1 & $\leq 0.06-8$ & 99.4 & 0.2 & 0.0 \\
\hline Linezolid & 1244 & 1 & 1 & $\leq 0.5-2$ & 100 & $N / A$ & - \\
\hline Vancomycin & 1244 & 0.5 & 0.5 & $\leq 0.12-2$ & 99.8 & $N / A$ & - \\
\hline \multicolumn{8}{|c|}{ Streptococcus pneumoniae } \\
\hline Tigecycline & 1602 & 0.03 & 0.12 & $\leq 0.008-1$ & $\mathrm{~N} / \mathrm{A}$ & $\mathrm{N} / \mathrm{A}$ & - \\
\hline Minocycline & 1602 & $\leq 0.25$ & 4 & $\leq 0.25$ to $\geq 16$ & 84.8 & 7.8 & -3.0 \\
\hline Penicillin & 1602 & $\leq 0.06$ & 1 & $\leq 0.06$ to $\geq 16$ & 72.4 & 9.3 & 4.1 \\
\hline Ampicillin & 1602 & $\leq 0.06$ & 2 & $\leq 0.06-8$ & N/A & $N / A$ & - \\
\hline AMC & 1602 & $\leq 0.03$ & 1 & $\leq 0.03$ to $\geq 16$ & 98.2 & 0.7 & 0.1 \\
\hline PIP/TAZ & 1602 & $\leq 0.25$ & 1 & $\leq 0.25$ to $\geq 32$ & N/A & $N / A$ & - \\
\hline Ceftriaxone & 1602 & $\leq 0.03$ & 0.5 & $\leq 0.03$ to $\geq 128$ & 98.4 & 0.4 & 0.0 \\
\hline Imipenem & 886 & $\leq 0.12$ & 0.25 & $\leq 0.12$ to $\geq 32$ & 84.5 & 1.5 & 0.0 \\
\hline Meropenem & 716 & $\leq 0.12$ & 0.5 & $\leq 0.12$ to $\geq 32$ & 83.7 & 7.1 & -1.5 \\
\hline Levofloxacin & 1602 & 0.5 & 1 & $\leq 0.06-32$ & 99.5 & 0.3 & 0.2 \\
\hline Linezolid & 1602 & $\leq 0.5$ & 1 & $\leq 0.5-2$ & 100 & $N / A$ & - \\
\hline Vancomycin & 1602 & 0.25 & 0.5 & $\leq 0.12-2$ & 99.9 & $N / A$ & - \\
\hline
\end{tabular}

$\mathrm{MIC}_{50 / 90}$, minimum inhibitory concentration for $50 \%$ and $90 \%$ of the organisms, respectively; \%S, \% susceptible; \%R, \% resistant; AMC, amoxicillin/clavulanic acid; PIP/TAZ, piperacillin/tazobactam; N/A, breakpoint not available.

${ }^{a}$ Change in resistance between 2004 and 2007, except for imipenem (change in resistance between 2004 and 2005) and meropenem (change in resistance between 2006 and 2007); a negative value indicates a drop in resistance during the corresponding interval. 
${ }^{\mathrm{b}}$ Percentages given to two decimal places where rounding would have erroneously indicated $100 \%$ susceptibility or $0.0 \%$ resistance. 
Table 2

Minimum inhibitory concentrations (MICs) and antimicrobial susceptibility of pooled resistant Gram-negative and Gram-positive organisms

\begin{tabular}{|c|c|c|c|}
\hline \multirow{2}{*}{ Organism } & \multirow[t]{2}{*}{$N$} & MIC (mg/L) & Susceptibility \\
\hline & & $\mathrm{MIC}_{50} \quad \mathrm{MIC}_{90}$ Range & $\% \mathrm{~S} \quad \% \mathrm{R}$ \\
\hline
\end{tabular}

Gram-negative

MDR Acinetobacter baumannii

$\begin{array}{llllllll}\text { Tigecycline } & 245 & 1 & 2 & \leq 0.008-8 & \text { N/A } & \text { N/A } & - \\ \text { Minocycline } & 245 & 1 & 8 & \leq 0.5 \text { to } \geq 32 & 86.5 & 4.9 & -7.2 \\ \text { Ampicillin } & 245 & \geq 64 & \geq 64 & 2 \text { to } \geq 64 & \text { N/A } & \text { N/A } & - \\ \text { AMC } & 245 & \geq 64 & \geq 64 & 1 \text { to } \geq 64 & \text { N/A } & \text { N/A } & - \\ \text { PIP/TAZ } & 245 & \geq 256 & \geq 256 & 0.25 \text { to } \geq 256 & 4.9 & 86.1 & -5.2 \\ \text { Ceftazidime } & 245 & \geq 64 & \geq 64 & \leq 8 \text { to } \geq 64 & 1.2 & 95.5 & 6.6 \\ \text { Ceftriaxone } & 245 & \geq 128 & \geq 128 & 8 \text { to } \geq 128 & 0.4 & 97.1 & 2.2 \\ \text { Cefepime } & 245 & 32 & \geq 64 & 8 \text { to } \geq 64 & 4.9 & 78.0 & 10.1 \\ \text { Imipenem } & 120 & 16 & \geq 32 & 0.5 \text { to } \geq 32 & 39.2 & 55.8 & -45.4 \\ \text { Meropenem } & 125 & 16 & \geq 32 & 0.5 \text { to } \geq 32 & 24.0 & 66.4 & -17.9 \\ \text { Levofloxacin } & 245 & \geq 16 & \geq 16 & 8 \text { to } \geq 16 & 0.0 & 100 & 0.0 \\ \text { Amikacin } & 245 & \geq 128 & \geq 128 & 64 \text { to } \geq 128 & 0.0 & 100 & 0.0\end{array}$

ESBL-positive Escherichia coli

$\begin{array}{llllllll}\text { Tigecycline } & 289 & 0.25 & 0.5 & 0.03-2 & 98.3 & 0.0 & 0.0 \\ \text { Minocycline } & 289 & 4 & 16 & \leq 0.5 \text { to } \geq 32 & 62.6 & 23.2 & 4.1 \\ \text { Ampicillin }^{\text {b }} & 289 & \geq 64 & \geq 64 & 2 \text { to } \geq 64 & 0.0 & 100 & - \\ \text { AMC } & 289 & 16 & 32 & 0.5 \text { to } \geq 64 & 25.3 & 30.8 & -11.4 \\ \text { PIP/TAZ } & 289 & 8 & 128 & 0.25 \text { to } \geq 256 & 74.4 & 12.5 & 1.6 \\ \text { Ceftazidime }^{\text {b }} & 289 & 16 & \geq 64 & \leq 8 \text { to } \geq 64 & 0.0 & 100 & - \\ \text { Ceftriaxone }^{\text {b }} & 289 & \geq 128 & \geq 128 & \leq 0.06 \text { to } \geq 128 & 0.0 & 100 & - \\ \text { Cefepime }^{\text {b }} & 289 & 32 & \geq 64 & \leq 0.5 \text { to } \geq 64 & 0.0 & 100 & - \\ \text { Imipenem }^{2} & 169 & 0.25 & 0.5 & \leq 0.06-4 & 100 & 0.0 & 0.0 \\ \text { Meropenem }^{2} & 120 & \leq 0.06 & 0.12 & \leq 0.06-0.5 & 100 & 0.0 & 0.0 \\ \text { Levofloxacin }^{2} & 289 & \geq 16 & \geq 16 & \leq 0.008 \text { to } \geq 16 & 25.3 & 69.9 & 0.7 \\ \text { Amikacin } & 289 & 4 & 16 & \leq 0.5 \text { to } \geq 128 & 91.3 & 3.8 & -1.2\end{array}$


ESBL-positive Klebsiella pneumoniae

$\begin{array}{llllllll}\text { Tigecycline } & 316 & 0.5 & 2 & 0.06-8 & 75.9 & 8.5 & -12.5\end{array}$

$\begin{array}{lllllll}\text { Minocycline } & 316 & 4 & \geq 32 & \leq 0.5 \text { to } \geq 32 \quad 50.0 & 34.8 & 8.9\end{array}$

Ampicillin $^{\mathrm{b}} \quad 316 \geq 64 \geq 64 \geq 64 \quad 0.0 \quad 100 \quad-$

$\begin{array}{llllllll}\text { AMC } & 316 & 16 & \geq 64 & 4 \text { to } \geq 64 & 23.7 & 40.5 & 18.4\end{array}$

$\begin{array}{llllllll}\text { PIP/TAZ } & 316 & 16 & \geq 256 & 1 \text { to } \geq 256 & 50.3 & 32.9 & 15.1\end{array}$

Ceftazidime $^{\mathrm{b}} 316 \geq 64 \geq 64 \leq 8$ to $\geq 64 \quad 0.0 \quad 100 \quad-$

Ceftriaxone $^{\mathrm{b}} \quad 316 \geq 128 \quad \geq 128 \quad 0.12$ to $\geq 128 \quad 0.0 \quad 100 \quad-$

Cefepime $^{b} \quad 316 \quad 16 \quad \geq 64 \leq 0.5$ to $\geq 64 \quad 0.0 \quad 100 \quad-$

$\begin{array}{llllllll}\text { Imipenem } & 174 & 0.25 & 0.5 & \leq 0.06-4 & 100 & 0.0 & 0.0\end{array}$

$\begin{array}{llllllll}\text { Meropenem } \quad 142 \leq 0.06 \quad 2 & \leq 0.06-8 & 99.3 & 0.0 & 0.0\end{array}$

$\begin{array}{lllllll}\text { Levofloxacin } 316 & 4 & \geq 16 & \leq 0.008 \text { to } \geq 16 \quad 46.5 & 42.4 & 17.5\end{array}$

$\begin{array}{llllllll}\text { Amikacin } & 316 & 4 & 32 & \leq 0.5 \text { to } \geq 128 & 88.6 & 7.6 & 2.6\end{array}$

$\beta$-Lactamase-positive Haemophilus influenzae

$\begin{array}{llllll}\text { Tigecycline } & 239 & 0.12 & 0.5 & \leq 0.008-2 & \text { N/A N/A }\end{array}$

$\begin{array}{lllllll}\text { Minocycline } & 239 \leq 0.5 & 2 & \leq 0.5-4 & 97.9 & 0.0 & 0.0\end{array}$

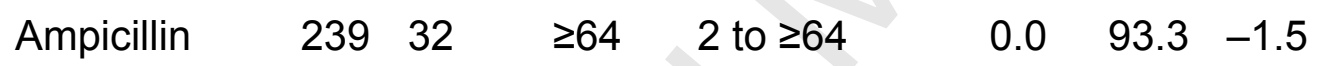

$\begin{array}{llllllll}\text { AMC } & 239 & 1 & 2 & \leq 0.12-32 & 97.5 & 2.5 & 1.3\end{array}$

$\begin{array}{llllllll}\text { PIP/TAZ } & 239 & \leq 0.06 & 0.12 & \leq 0.06-16 & 98.7 & 1.3 & 0.0\end{array}$

Ceftriaxone $239 \leq 0.06 \leq 0.06 \leq 0.06-32 \quad 99.6 \quad$ N/A -

Cefepime $239 \leq 0.5 \leq 0.5 \leq 0.5-8 \quad 98.3 \quad$ N/A -

$\begin{array}{lllllll}\text { Imipenem } & 143 & 0.25 & 1 & \leq 0.06-2 & 100 & \text { N/A - }\end{array}$

Meropenem $96 \leq 0.06 \quad 0.12 \leq 0.06-0.25 \quad 100 \quad$ N/A -

$\begin{array}{lllllll}\text { Levofloxacin } & 239 & 0.015 & 0.03 & \leq 0.008-1 & 100 & \text { N/A }\end{array}$

$\begin{array}{lllllll}\text { Amikacin } & 239 & 4 & 8 & \leq 0.5-32 & \text { N/A N/A }\end{array}$

Gram-positive

Vancomycin-resistant Enterococcus faecium

$\begin{array}{lllllll}\text { Tigecycline } & 77 & 0.06 & 0.12 & 0.015-0.25 & \text { N/A } & \text { N/A }\end{array}$

$\begin{array}{llllllll}\text { Minocycline } \quad 77 & \leq 0.25 & \geq 16 & \leq 0.25 \text { to } \geq 16 & 71.4 & 14.3 & 7.7\end{array}$

$\begin{array}{llllllll}\text { Penicillin } \quad 77 \quad \geq 16 & \geq 16 \quad 4 \text { to } \geq 16 & 1.3 & 98.7 & 7.7\end{array}$

$\begin{array}{llllllll}\text { Ampicillin } \quad 77 \quad \geq 32 \quad \geq 32 & 0.5 \text { to } \geq 32 \quad 3.9 & 96.1 & 23.1\end{array}$

AMC $\quad 77 \geq 16 \geq 16 \quad 1$ to $\geq 16 \quad$ N/A N/A -

$\begin{array}{llllllll}\text { PIP/TAZ } & 77 & \geq 32 & \geq 32 & 4 \text { to } \geq 32 \quad \text { N/A } & \text { N/A } & -\end{array}$ 


\begin{tabular}{|c|c|c|c|c|c|c|c|}
\hline Ceftriaxone & 77 & $\geq 128$ & $\geq 128$ & 4 to $\geq 128$ & N/A & $\mathrm{N} / \mathrm{A}$ & - \\
\hline Imipenem & 48 & $\geq 32$ & $\geq 32$ & 1 to $\geq 32$ & $\mathrm{~N} / \mathrm{A}$ & $\mathrm{N} / \mathrm{A}$ & - \\
\hline Meropenem & 29 & $\geq 32$ & $\geq 32$ & $\geq 32$ & N/A & $\mathrm{N} / \mathrm{A}$ & - \\
\hline Levofloxacin & 77 & $\geq 64$ & $\geq 64$ & 2 to $\geq 64$ & 2.6 & 97.4 & 15.4 \\
\hline Linezolid & 77 & 2 & 4 & $\leq 0.5-4$ & 79.2 & 0.0 & 0.0 \\
\hline Vancomycin & 77 & $\geq 64$ & $\geq 64$ & 32 to $\geq 64$ & 0.0 & 100 & 0.0 \\
\hline \multicolumn{8}{|c|}{ Meticillin-resistant Staphylococcus aureus (MRSA) } \\
\hline Tigecycline & 853 & 0.12 & 0.25 & $0.03-1$ & 99.9 & 0.1 & 0.0 \\
\hline Minocycline & 853 & $\leq 0.25$ & 4 & $\leq 0.25$ to $\geq 16$ & 96.1 & 0.7 & 1.1 \\
\hline Penicillin ${ }^{c}$ & 853 & $\geq 16$ & $\geq 16$ & 0.25 to $\geq 16$ & 0.0 & 100 & - \\
\hline Ampicillin ${ }^{c}$ & 853 & $\geq 32$ & $\geq 32$ & 0.5 to $\geq 32$ & 0.0 & 100 & - \\
\hline $\mathrm{AMC}^{\mathrm{C}}$ & 853 & 8 & $\geq 16$ & 0.25 to $\geq 16$ & 0.0 & 100 & - \\
\hline PIP/TAZ ${ }^{c}$ & 853 & $\geq 32$ & $\geq 32$ & $\leq 0.25$ to $\geq 32$ & 0.0 & 100 & - \\
\hline Ceftriaxone $^{c}$ & 853 & 64 & $\geq 128$ & 0.12 to $\geq 128$ & 0.0 & 100 & - \\
\hline Imipenem $^{\mathrm{c}}$ & 441 & 2 & $\geq 32$ & $\leq 0.12$ to $\geq 32$ & 0.0 & 100 & - \\
\hline Meropenem $^{c}$ & 412 & 2 & $\geq 32$ & $\leq 0.12$ to $\geq 32$ & 0.0 & 100 & - \\
\hline Levofloxacin & 853 & 8 & 32 & $\leq 0.06$ to $\geq 64$ & 13.1 & 83.8 & 4.8 \\
\hline Linezolid & 853 & 2 & 4 & $\leq 0.5-4$ & 100 & $\mathrm{~N} / \mathrm{A}$ & - \\
\hline Vancomycin & 853 & 1 & 1 & $\leq 0.12-2$ & 100 & 0.0 & 0.0 \\
\hline \multicolumn{8}{|c|}{ Penicillin-resistant Streptococcus pneumoniae } \\
\hline Tigecycline & 149 & 0.03 & 0.12 & $\leq 0.008-0.12$ & $\mathrm{~N} / \mathrm{A}$ & $\mathrm{N} / \mathrm{A}$ & - \\
\hline Minocycline & 149 & 2 & 8 & $\leq 0.25$ to $\geq 16$ & 63.1 & 12.1 & -8.5 \\
\hline Penicillin & 149 & 2 & 4 & 2 to $\geq 16$ & 0.0 & 100 & 0.0 \\
\hline Ampicillin & 149 & 2 & 4 & $1-8$ & $\mathrm{~N} / \mathrm{A}$ & $\mathrm{N} / \mathrm{A}$ & - \\
\hline AMC & 149 & 2 & 4 & 0.5 to $\geq 16$ & 81.9 & 8.1 & -3.2 \\
\hline $\mathrm{PIP} / \mathrm{TAZ}$ & 149 & 2 & 4 & 0.5 to $\geq 32$ & $\mathrm{~N} / \mathrm{A}$ & $\mathrm{N} / \mathrm{A}$ & - \\
\hline Ceftriaxone & 149 & 1 & 2 & 0.5 to $\geq 128$ & 87.2 & 3.4 & -1.7 \\
\hline Imipenem & 50 & 0.5 & 0.5 & $0.25-4$ & 0.0 & 10.0 & 0.0 \\
\hline Meropenem & 99 & 1 & 1 & $\leq 0.12$ to $\geq 32$ & 4.0 & 50.5 & 1.7 \\
\hline Levofloxacin & 149 & 0.5 & 1 & $0.25-16$ & 99.3 & 0.7 & 0.0 \\
\hline Linezolid & 149 & 1 & 1 & $\leq 0.5-2$ & 100 & $\mathrm{~N} / \mathrm{A}$ & - \\
\hline Vancomycin & 149 & 0.25 & 0.5 & $\leq 0.12-2$ & 98.7 & N/A & - \\
\hline
\end{tabular}


$\mathrm{MIC}_{50 / 90}$, minimum inhibitory concentration for $50 \%$ and $90 \%$ of the organisms, respectively; \%S, \% susceptible; \%R, \% resistant; MDR, multidrug-resistant; AMC, amoxicillin/clavulanic acid; PIP/TAZ, piperacillin/tazobactam; ESBL, extendedspectrum $\beta$-lactamase; N/A, breakpoint not available; CLSI, Clinical and Laboratory Standards Institute.

${ }^{a}$ Change in resistance between 2004 and 2007, except for imipenem (change in resistance between 2004 and 2005) and meropenem (change in resistance between 2006 and 2007); a negative value indicates a drop in resistance during the corresponding interval.

${ }^{\mathrm{b}}$ All ESBL-producers defined as resistant according to CLSI guidelines [10].

${ }^{c}$ All MRSA defined as resistant according to CLSI guidelines [10]. 
Table 3

Prevalence of resistant Gram-negative and Gram-positive organisms collected across Europe (among countries where the total number of isolates collected was $\geq 10$ in 3 or 4 years) between 2004 and 2007

\begin{tabular}{|c|c|c|c|c|c|c|}
\hline \multirow{2}{*}{ Organism } & \multirow[t]{2}{*}{ Country } & 2004 & 2005 & 2006 & 2007 & 2004-2007 \\
\hline & & $n(\%)$ & $n(\%)$ & $n(\%)$ & $n(\%)$ & $n(\%)$ \\
\hline
\end{tabular}

\section{Gram-negative}

MDR Acinetobacter baumannii ${ }^{\text {a }}$

\begin{tabular}{lllllllllll} 
Belgium & 13 & $2(15.4)$ & 18 & $2(11.1)$ & 40 & $1(2.5)$ & 38 & $9(23.7)$ & 109 & $14(12.8)$ \\
France & 53 & $2(3.8)$ & 26 & $0(0.0)$ & 102 & $6(5.9)$ & 98 & $6(6.1)$ & 279 & $14(5.0)$ \\
Germany & 47 & $1(2.1)$ & 21 & $0(0.0)$ & 47 & $2(4.3)$ & 72 & $1(1.4)$ & 187 & $4(2.1)$ \\
Greece & 20 & $10(50.0)$ & 10 & $4(40.0)$ & 39 & $16(41.0)$ & 25 & $17(68.0)$ & 94 & $47(50.0)$ \\
Hungary & 15 & $1(6.7)$ & 14 & $1(7.1)$ & 0 & $0(-)$ & 10 & $0(0.0)$ & 39 & $2(5.1)$ \\
Ireland & 11 & $0(0.0)$ & 11 & $3(27.3)$ & 12 & $1(8.3)$ & 16 & $0(0.0)$ & 50 & $4(8.0)$ \\
Italy & 47 & $9(19.1)$ & 51 & $8(15.7)$ & 110 & $45(40.9)$ & 75 & $40(53.3)$ & 283 & $102(36.0)$ \\
Spain & 70 & $25(35.7)$ & 27 & $3(11.1)$ & 1 & $1(-)$ & 53 & $8(15.1)$ & 151 & $37(24.5)$ \\
Europe & 371 & $60(16.2)$ & 208 & $21(10.1)$ & 472 & $76(16.1)$ & 509 & $88(17.3)$ & 1560 & $245(15.7)$ \\
sitive Escherichia coli & & & & & & & & \\
Belgium & 15 & $0(0.0)$ & 58 & $9(15.5)$ & 51 & $6(11.8)$ & 97 & $2(2.1)$ & 221 & $17(7.7)$ \\
France & 100 & $3(3.0)$ & 54 & $1(1.9)$ & 173 & $8(4.6)$ & 204 & $15(7.4)$ & 531 & $27(5.1)$ \\
Germany & 120 & $6(5.0)$ & 50 & $1(2.0)$ & 128 & $10(7.8)$ & 125 & $20(16.0)$ & 423 & $37(8.7)$ \\
\hline
\end{tabular}




\begin{tabular}{|c|c|c|c|c|c|c|c|c|c|c|}
\hline Greece & 24 & $2(8.3)$ & 18 & $5(27.8)$ & 82 & $21(25.6)$ & 28 & $5(17.9)$ & 152 & $33(21.7)$ \\
\hline Ireland & 24 & $0(0.0)$ & 28 & $1(3.6)$ & 28 & $6(21.4)$ & 45 & $9(20.0)$ & 125 & $16(12.8)$ \\
\hline Italy & 91 & $15(16.5)$ & 139 & $16(11.5)$ & 249 & $22(8.8)$ & 190 & $27(14.2)$ & 669 & $80(12.0)$ \\
\hline Spain & 101 & $1(1.0)$ & 102 & $3(2.9)$ & 0 & $0(-)$ & 101 & $13(12.9)$ & 304 & $17(5.6)$ \\
\hline Sweden & 0 & $0(-)$ & 25 & $3(12.0)$ & 62 & $1(1.6)$ & 13 & $0(0.0)$ & 100 & $4(4.0)$ \\
\hline Europe & 749 & $47(6.3)$ & 501 & $42(8.4)$ & 1049 & $85(8.1)$ & 1104 & 115 (10.4) & 3403 & $289(8.5)$ \\
\hline \multicolumn{11}{|c|}{ ESBL-positive Klebsiella pneumoniae } \\
\hline Belgium & 28 & $2(7.1)$ & 15 & $2(13.3)$ & 31 & $5(16.1)$ & 63 & $6(9.5)$ & 137 & $15(10.9)$ \\
\hline France & 66 & $5(7.6)$ & 54 & $5(9.3)$ & 87 & $7(8.0)$ & 129 & $16(12.4)$ & 336 & $33(9.8)$ \\
\hline Germany & 77 & $4(5.2)$ & 27 & $2(7.4)$ & 62 & $4(6.5)$ & 84 & $7(8.3)$ & 250 & $17(6.8)$ \\
\hline Greece & 24 & $7(29.2)$ & 16 & $0(0.0)$ & 69 & $25(36.2)$ & 26 & $4(15.4)$ & 135 & $36(26.7)$ \\
\hline Ireland & 22 & $0(0.0)$ & 26 & $1(3.8)$ & 20 & $0(0.0)$ & 36 & $5(13.9)$ & 104 & $6(5.8)$ \\
\hline Italy & 77 & $25(32.5)$ & 86 & $18(20.9)$ & 180 & $12(6.7)$ & 127 & $34(26.8)$ & 470 & 89 (18.9) \\
\hline Spain & 80 & $7(8.8)$ & 64 & $3(4.7)$ & 0 & $0(-)$ & 69 & $6(8.7)$ & 213 & $16(7.5)$ \\
\hline Europe & 564 & $80(14.2)$ & 321 & $32(10.0)$ & 667 & $72(10.8)$ & 779 & $132(16.9)$ & 2331 & $316(13.6)$ \\
\hline \multicolumn{11}{|c|}{$\beta$-Lactamase-positive Haemophilus influenzae } \\
\hline Belgium & 15 & $1(6.7)$ & 19 & $1(5.3)$ & 20 & $2(10.0)$ & 59 & $9(15.3)$ & 113 & $13(11.5)$ \\
\hline France & 56 & $13(23.2)$ & 29 & $9(31.0)$ & 57 & $13(22.8)$ & 125 & $23(18.4)$ & 267 & $58(21.7)$ \\
\hline Germany & 72 & $7(9.7)$ & 15 & $2(13.3)$ & 36 & $2(5.6)$ & 74 & $3(4.1)$ & 197 & $14(7.1)$ \\
\hline Ireland & 14 & $1(7.1)$ & 0 & $0(-)$ & 27 & 9 (33.3) & 25 & $7(28.0)$ & 66 & $17(25.8)$ \\
\hline Italy & 45 & $5(11.1)$ & 73 & $13(17.8)$ & 90 & $8(8.9)$ & 63 & $11(17.5)$ & 271 & $37(13.7)$ \\
\hline
\end{tabular}




\begin{tabular}{|c|c|c|c|c|c|c|c|c|c|c|}
\hline Spain & 60 & $14(23.3)$ & 56 & $9(16.1)$ & 0 & $0(-)$ & 56 & $10(17.9)$ & 172 & $33(19.2)$ \\
\hline Sweden & 0 & $0(-)$ & 12 & $3(25.0)$ & 32 & $3(9.4)$ & 15 & $4(26.7)$ & 59 & $10(16.9)$ \\
\hline Europe & 431 & $63(14.6)$ & 214 & $40(18.7)$ & 456 & $59(12.9)$ & 533 & $77(14.4)$ & 1634 & 239 (14.6) \\
\hline \multicolumn{11}{|l|}{ Gram-positive } \\
\hline \multicolumn{11}{|c|}{ Vancomycin-resistant Enterococcus faecalis ${ }^{\mathrm{b}}$} \\
\hline Greece & 10 & $0(0.0)$ & 6 & $0(-)$ & 32 & $1(3.1)$ & 13 & $0(0.0)$ & 61 & $1(1.6)$ \\
\hline Italy & 32 & $6(18.8)$ & 53 & $2(3.8)$ & 105 & $3(2.9)$ & 77 & $2(2.6)$ & 267 & $13(4.9)$ \\
\hline Europe & 347 & $6(1.7)$ & 205 & $3(1.5)$ & 396 & $4(1.0)$ & 485 & $4(0.8)$ & 1433 & $17(1.2)$ \\
\hline \multicolumn{11}{|c|}{ Vancomycin-resistant Enterococcus faecium } \\
\hline Germany & 14 & $1(7.1)$ & 12 & $1(8.3)$ & 27 & $2(7.4)$ & 23 & $9(39.1)$ & 76 & $13(17.1)$ \\
\hline Italy & 22 & $4(18.2)$ & 16 & $4(25.0)$ & 42 & $19(45.2)$ & 16 & $2(12.5)$ & 96 & $29(30.2)$ \\
\hline Europe & 104 & $13(12.5)$ & 73 & $9(12.3)$ & 153 & $29(19.0)$ & 161 & $26(16.1)$ & 491 & 77 (15.7) \\
\hline \multicolumn{11}{|c|}{ Meticillin-resistant Staphylococcus aureus } \\
\hline Belgium & 25 & $9(36.0)$ & 49 & $7(14.3)$ & 33 & $16(48.5)$ & 103 & $23(22.3)$ & 210 & $55(26.2)$ \\
\hline France & 95 & $34(35.8)$ & 63 & $20(31.7)$ & 130 & $40(30.8)$ & 220 & $66(30.0)$ & 508 & $160(31.5)$ \\
\hline Germany & 115 & $12(10.4)$ & 46 & $22(47.8)$ & 96 & $15(15.6)$ & 139 & $25(18.0)$ & 396 & $74(18.7)$ \\
\hline Greece & 26 & $19(73.1)$ & 24 & $7(29.2)$ & 77 & $36(46.8)$ & 35 & $17(48.6)$ & 162 & 79 (48.8) \\
\hline Ireland & 25 & $7(28.0)$ & 10 & $0(0.0)$ & 39 & $7(17.9)$ & 41 & $11(26.8)$ & 115 & $25(21.7)$ \\
\hline Italy & 91 & $41(45.1)$ & 112 & $44(39.3)$ & 217 & $73(33.6)$ & 169 & $47(27.8)$ & 589 & $205(34.8)$ \\
\hline Spain & 99 & $27(27.3)$ & 97 & $13(13.4)$ & 0 & $0(-)$ & 97 & $32(33.0)$ & 293 & $72(24.6)$ \\
\hline Sweden & 0 & $0(-)$ & 24 & $2(8.3)$ & 38 & $12(31.6)$ & 20 & $11(55.0)$ & 82 & $25(30.5)$ \\
\hline
\end{tabular}




\section{$\begin{array}{lllllllllll}\text { Europe } & 744 & 214(28.8) & 453 & 121(26.7) & 888 & 235(26.5) & 1133 & 283(25.0) & 3218 & 853(26.5)\end{array}$}

Penicillin-resistant Streptococcus pneumoniae

$\begin{array}{lllllllllll}\text { Belgium } & 1 & 0(-) & 26 & 1(3.8) & 31 & 3(9.7) & 56 & 5(8.9) & 114 & 9(7.9) \\ \text { France } & 54 & 10(18.5) & 30 & 5(16.7) & 66 & 12(18.2) & 118 & 18(15.3) & 268 & 45(16.8) \\ \text { Germany } & 72 & 0(0.0) & 19 & 1(5.3) & 62 & 1(1.6) & 57 & 2(3.5) & 210 & 4(1.9) \\ \text { Ireland } & 15 & 0(0.0) & 1 & 1(-) & 32 & 5(15.6) & 24 & 7(29.2) & 72 & 13(18.1) \\ \text { Italy } & 43 & 2(4.7) & 67 & 3(4.5) & 112 & 6(5.4) & 62 & 4(6.5) & 284 & 15(5.3) \\ \text { Spain } & 57 & 7(12.3) & 54 & 12(22.2) & 0 & 0(-) & 37 & 6(16.2) & 148 & 25(16.9) \\ \text { Europe } & 396 & 28(7.1) & 233 & 26(11.2) & 498 & 42(8.4) & 475 & 53(11.2) & 1602 & 149(9.3)\end{array}$

MDR, multidrug-resistant; ESBL, extended-spectrum $\beta$-lactamase.

${ }^{a} \geq 10$ Acinetobacter baumannii isolates were contributed from Sweden in 2005, 2006 and 2007 but no MDR isolates were contributed, thus Sweden is not listed here.

${ }^{b} \geq 10$ Enterococcus faecalis isolates were contributed from Belgium, France, Germany and Spain in 3 or 4 years between 2004 and 2007 but no vancomycin-resistant isolates were contributed, thus these countries are not listed here. 